\title{
Above-ground tree biomass and allometric relationships of Cinnamomum tamala grown in the western hill regions of Nepal
}

\begin{abstract}
B. S. Poudel ${ }^{1 *}$, S.K. Gautam ${ }^{1}$ and D. N. Bhandari ${ }^{2}$
Biomass regression models are presented describing total above-ground biomass, stem wood, branch wood, foliage and bark production for Tejpat (Cinnamomum tamala), a multipurpose tree which is found abundantly distributed and grown in western hill districts of Nepal. A total of 56 Tejpat trees between 6.2 and $16.5 \mathrm{~cm}$ diameter at breast height (DBH) from farmers' farmland and marginal land in Arghakhanchi, Gulmi and Palpa districts were sampled and harvested. Mean fresh weight of total above-ground biomass, stem wood, branch wood, foliage and bark was $77.03,36.39,15.16,17.53$ and $8.2 \mathrm{~kg}^{-1} \mathrm{tree}^{-1}$, respectively. Allocation of biomass was more in stem $\left(47.24 \%\right.$ tree $\left.^{-1}\right)$ than in foliage $\left(22.75 \%\right.$ tree $\left.^{-1}\right)$, branch $\left(19.69 \%\right.$ tree $\left.^{-1}\right)$ and bark $\left(10.31 \%\right.$ tree $\left.^{-1}\right)$. Weight of tree component was estimated as a function of $\mathrm{DBH}$. After removal of the outliers, data were randomly divided into two datasets: $70 \%$ for model calibration and another $30 \%$ for model validation. Correlation analysis showed positive stronger linear relationship between DBH and biomass. Five regression models (linear, logarithmic, quadratic, power and exponential) were developed. All models were statistically significant, with $R^{2}$ ranging from 0.64 to 0.83 . Model validation was based on root mean square error (RMSE). RMSE percentage for the best-fit equation varied between $16.64 \%$ and $44.82 \%$. Linear model resulted in the least error and was selected as the best-fit model for prediction of biomass of bark, foliage, branch, stem and total above ground tree biomass. Biomass models developed could be applied to obtain biomass of different tree components of Tejpat grown in the study area and could even be applied to other areas which have similar conditions; but it should be validated before using them in new sites and conditions.
\end{abstract}

Key words: Regression models, fresh weight, bark, foliage, branch wood, stem wood

B iomass is the total amount of living organic matter accumulation on a unit area at a specified point of time (Brown, 1997; Applegate et al., 1988). Tree biomass, which is used to denote the total quantity of materials in a tree, can best be measured in terms of weight (Poudel et al., 2003). Biomass can be estimated by direct method, i.e., destructive techniques or by indirect method, i.e., developing an allometric relationship. Destructive techniques for biomass estimation are time consuming and expensive (Nath et al., 2009; Verhijst and Telenius, 1999).

Allometric relationships yield a non-destructive and indirect estimates of biomass and is often the preferred approach since it is less time consuming and less expensive (St Clair, 1993) than the direct method. Allometric equations are widely used for forest biomass assessment. Allometric relationship through regression analysis has the advantage that once equations are developed and validated they can be used for similar forest types on a wide range of sites in a particular geographic region (Satto and Madgwick, 1982).

Biomass tables are similar to the volume tables in that they quantify the resources of interest (tree, stem wood, branch wood, foliage, bark) with reference to some measurement of the stand or tree, usually Diameter at Breast Height (DBH). Single tree biomass tables, which predict the weight of an individual tree from its diameter, have been found reliable (Applegate et al., 1985; Joshi, 1985; Hawkins, 1987). Previous biomass and volume tables in Nepal have been oriented towards traditional forestry practices focusing largely on timber production. Such tables are therefore largely concerned with only the timber species (Sharma and Pukkala, 1990). Some biomass

\footnotetext{
${ }^{1}$ Department of Forest Research and Survey, Babarmahal, Kathmandu

${ }^{2}$ Practical Action, Kathmandu

*Corresponding author: bspoudel@dfrs.gov.np
} 
information has been developed in the form of oven-dried forest products which makes it difficult to interpret by Forest User Group (FUG) members, whilst other information provides stem volume figures (Tamrakar, 1999) rather than branch, bark and foliage quantity which are equally important forest products for forest users. Most of the non-timber forest products are traded in terms of weight, often air-dry weight (Poudel et al., 2003). Biomass tables are the best means of estimating biomass of such parts in terms of weight based on field measurement of one variable i.e. DBH only.

Cinnamomum tamala (Buch.- Ham.) Nees and Eberm. under family Lauraceae, locally called as Tejpat, Dalchini, Sinkauli in Nepali, is a moderate sized evergreen tree species. It is distributed in tropical and subtropical Himalayas (Edwards, 1996) and grown between $500 \mathrm{~m}$ to $2000 \mathrm{~m}$ asl in Nepal (Jackson, 1994). It grows on varieties of soils. However, it prefers well-drained moist soils. Tejpat trees are extensively managed for leaf and bark production in Nepal. Bark and leaves are used as spices and medicine; wood as fuel wood, agricultural implements, and in some instances, as furniture and roofing material. Tejpat contains etheral oil in the leaves and cortex of cells (Rendle, 1979) that enrich the plant with aromatic flavour thereby making bark and leaves suitable for spices and medicine. Leaves are used in colic, diarrhoea, rheumatism and found beneficial for cough and cold, diabetic patient and to reduce blood sugar level (Kirtikar et al., 1992). Harvesting is done at the age of $8-10$ years. It coppices well and coppices are ready to harvest in the shorter period.

Cinnamomum tamala is one of the major non-timber forest product species in Gulmi, Arghakhanchi and Palpa districts. Its bark and leaves are sold easily at high prices and people are interested to plant this species and some stands already exist in their lands but they can not make precise estimation of the amount of bark and leaf (DFO Arghakhanchi, 2001). Tejpat is listed among 30 medicinal plants prioritized for research and development by the Government of Nepal (DPR, 2006).

The aim of this study was to develop allometric equations to estimate biomass of foliage, bark, stem wood and branch wood, and prepare a biomass table including the stem wood, branch wood, bark and foliage for green condition and, bark and foliage biomass for green, air-dry and oven-dry condition.

\section{Materials and methods}

\section{Study area}

The study was conducted in three hill districts i.e. Gulmi, Palpa and Arghakhanchi of Western Development Region, Nepal where both natural and farmer raised stands of Cinnamomum tamala exist. The bark and leaf are commercially traded from these districts to Butwal and then exported to India. Total area covered by these districts is $3,708 \mathrm{~km}^{2}$ (Fig. 1).

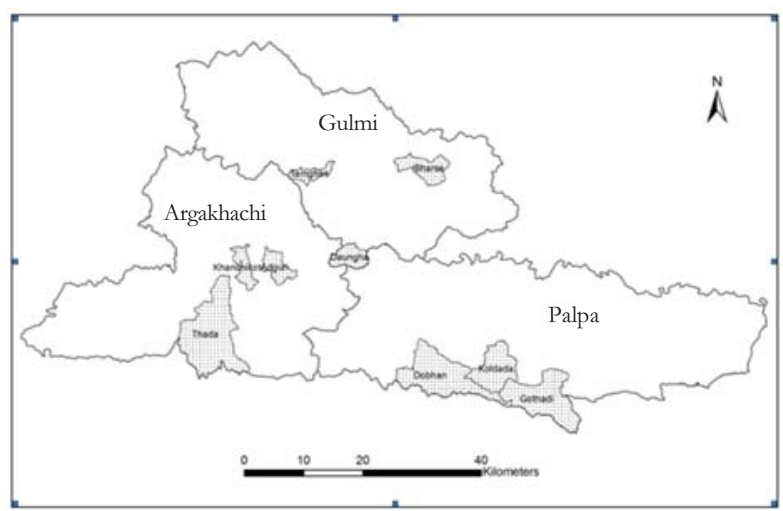

The climate of the study area is subtropical.

Fig 1: Map showing study areas

Tejpat is widely distributed and frequently planted in Narpani, Thanda Daha, Sitapur, Adguri, Khidim, Pokharathok, Datibang and Sidhdhara VDCs in Arghakhanchi district (DFO Arghakhanchi, 2001); Tamghas, Archale, Damuwa, Bharse, Gwaga, Purkot, Musikot, Mankot, Arlangkot, Malagiri and Isma VDCs in Gulmi district (DFO Gulmi, 2001); and Koldanda, Dovan, Gothandi, Barlyangadi, Styawati, Bhuwanpokhari and Masyam VDCs in Palpa district (DFO Palpa, 2001). The species is grown mainly in private lands especially on the terrace risers and marginal lands (grass fields and gullies). There are a few natural stands in community and national forests in these districts.

Village Development Committee (VDC) containing natural and planted Tejpat stands were listed for each district separately by consulting respective district forest offices, potential traders and the secondary information. Three VDCs in each district (Narpani, Thanda Daha and Adguri in Arghakhanchi; Tamghas, Bharse and Damuwa in Gulmi; and Koldanda, Dovan and Gothandi in Palpa) were selected randomly from the list of VDCs. Since the 
community forests do not have sufficient trees to meet the objectives of the study. Therefore, Tejpat stands that have been grown in the private lands as part of agroforestry system or private woodlots were selected as study sites.

\section{Biomass estimation}

Biomass was determined destructively by harvesting randomly selected trees of different sizes. To make the data more representative, trees were classified into different size groups at the interval of $5 \mathrm{~cm}$ DBH class. Trees representative to each DBH class were chosen randomly in each site. Thus, a total of 56 (20 from Palpa, 18 each from Gulmi and Arghakhanchi district) were harvested for this study. These trees were cut in summer (September) 2002, so that this would coincide with the bark harvest time, which in study area is preferably summer because of ease of extraction of bark. DBH over bark measured $1.3 \mathrm{~m}$ above the ground level of each tree was taken before felling. After harvesting, total height was measured.

All trees divided into following components: stem wood, branch wood, foliage and bark. Components were separated and fresh weight of each component was weighed in the field. For determination of airdry and oven-dry weight of bark and foliage, composite sub-samples of bark of six trees from $1.3 \mathrm{~m}$ above the ground level and composite subsample of foliage from several branches of six trees were taken to laboratory of Institute of Forestry, Pokhara. Fresh weights of the composite subsamples were measured. Air-dry weight was obtained by drying the sub-samples in the sun for about one week. Oven-dry weight was obtained after drying at $105^{\circ} \mathrm{C}$ for about 48 hours in oven to constant weight. The dry mass of the bark and foliage components were then calculated. Oven-dry weight to fresh weight ratio was used to convert fresh weight to oven dry weight. Summing all the biomass components yielded the above-ground tree standing biomass.

\section{Statistical analysis}

Statistical analyses were carried out using SPSS 11.0. Descriptive statistics, parameter estimates and regression coefficients were estimated. One-way ANOVA was used. Some candidate models (linear, logarithmic, quadratic, power, cubic and exponential) were analysed and compared. Model performance was assessed on the basis of various indexes. First, the coefficient of determination $\left(\mathrm{R}^{2}\right)$ of each model was computed. Significance of regression coefficients were assessed by t-statistics and significance of regression model were assessed by F-statistics. Besides, SEE, F-value and T-value of the parameters were computed. The best fit-model based on $\mathrm{R}^{2}$, SEE and F-value, was selected and used to predict biomass. Regression lines between observed and predicted biomass values of sampled trees were compared. Regression models were compared for their predictive accuracy by using root mean square error (RMSE) (Gill et al., 2000; Leboeuf et al., 2007). RMSE was calculated by using the following formulae (Wallace and Goffinet. 1989):

$$
\text { RMSE }=\sqrt{\sum_{i=1}^{16}\left(X_{i}-Y_{i}\right) / N}
$$

RMSE $(\%)=($ RMSE $/ \quad \mathrm{X}) * 100 \%$

Where $\mathrm{X}_{i}=$ Measured biomass, $\mathrm{Y}_{i}=$ Predicted biomass by the model, $\bar{N}=$ Number of sample and $\mathrm{X}=$ Mean of the validation data

After the removal of three outliers, the 53 trees were randomly divided into two sets: $37(70 \%)$ for model development as training dataset and another $16(30 \%)$ for model validation as test datasets. The models were validated using $30 \%$ datasets for calculation of RMSE. The $\mathrm{R}^{2}$ from the training and RMSE $\%$ from the validation dataset was used to assess the strength of the model.

\section{Results and discussion}

\section{Sample trees characterization}

Box plot diagram was executed in SPSS Program and a total of three datasets were found outliers and thus, removed from the data sets for correlation and

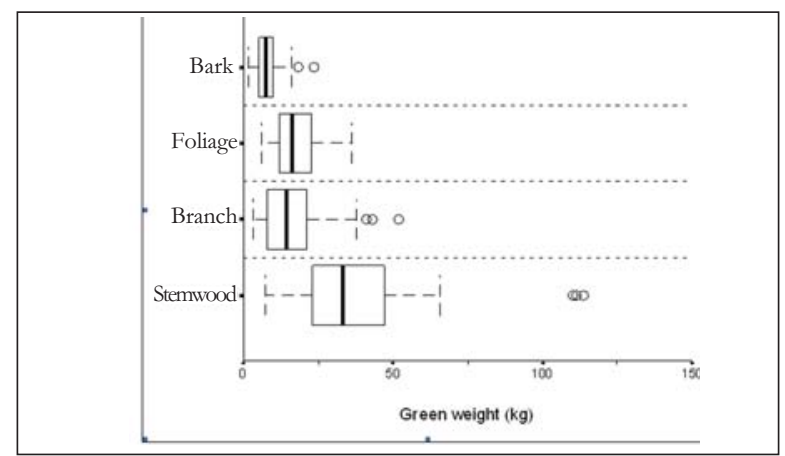

regression analysis (Fig. 2). 
Mean DBH of the sampled trees $(\mathrm{N}=37)$ was 10.86 $\mathrm{cm}$, with a standard error of mean of 0.35 and range of $8.60 \mathrm{~cm}$. Mean height was $9.74 \mathrm{~m}$ (standard error of mean: 0.34 and range: 11.35). Mean green weight of foliage, bark, branch wood, stem wood and total above-ground tree biomass was $17.53,7.95,15.16$, 36.39 and $77.03 \mathrm{~kg}$, respectively. Descriptive statistics of DBH, height, foliage, bark, branch, stem wood and total above ground tree biomass are shown in table 1.

\section{Relationship between DBH and green weight}

Previous studies demonstrated that DBH is the most reliable variable for biomass estimation (Schroeder et al., 1997; Popescu, 2007). The use of DBH alone for above-ground biomass estimation is common and it is one of the universally used predictors, because it shows a high correlation with all tree biomass components and easy to obtain accurately (Zianis, 2008). Tree DBH was significantly and

Table 1: Descriptive statistics of tree characteristics and fresh weight of different tree components $(\mathrm{N}=37)$

\begin{tabular}{lllllll}
\hline Variable & Mean & Std. Deviation & Variance & Minimum & Maximum & Range \\
\hline DBH $(\mathrm{cm})$ & 10.86 & 2.13 & 4.55 & 6.90 & 15.50 & 8.60 \\
Height $(\mathrm{m})$ & 9.74 & 2.07 & 4.28 & 6.80 & 18.15 & 11.35 \\
Foliage $(\mathrm{kg})$ & 17.53 & 7.45 & 55.49 & 6.50 & 35.50 & 29.00 \\
Bark $(\mathrm{kg})$ & 7.95 & 3.28 & 10.73 & 1.75 & 16.00 & 14.25 \\
$\begin{array}{l}\text { Branch wood }(\mathrm{kg}) \\
\text { Stem wood }(\mathrm{kg})\end{array}$ & 15.16 & 9.17 & 84.00 & 3.00 & 41.00 & 38.00 \\
$\begin{array}{l}\text { Total above ground } \\
\text { tree }(\mathrm{kg})\end{array}$ & 15.79 & 249.24 & 7.00 & 66.00 & 59.00 \\
\hline
\end{tabular}

$\mathrm{DBH}$, height, green weight of bark and foliage of the validation datasets $(\mathrm{N}=16)$ ranged from 6.20 to $16.10 \mathrm{~cm}$ (mean 9.60), 6.20 to $12.10 \mathrm{~m}$ (mean 8.98), 3.0 to $13.0 \mathrm{~kg}$ (mean 6.67 ) and 6.0 to $32.5 \mathrm{~kg}$ (mean 16.22), respectively. The mean values of the model calibration data and validation data are similar. The highest share of above-ground biomass was contained in stem: $47.24 \%$, followed by foliage: 22.75\%, branch: $19.69 \%$ and bark: $10.31 \%$ (Fig. 3).

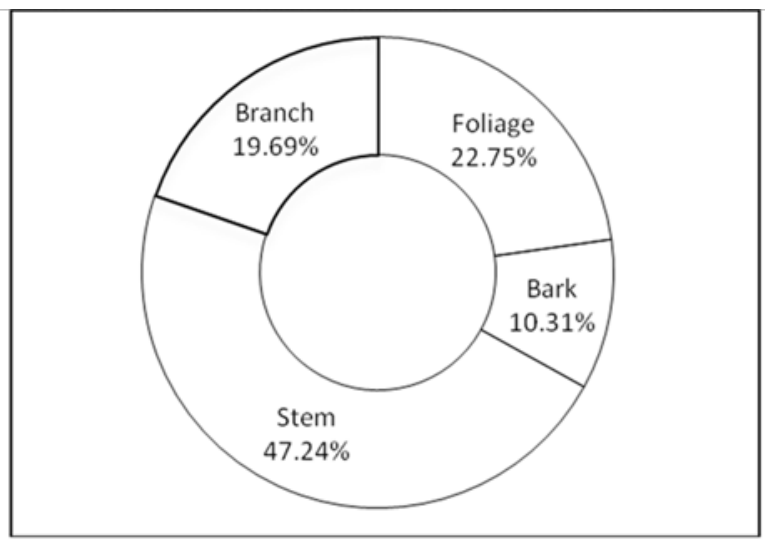

Fig 3: Biomass partitioning in above-ground Tejpat tree components positively correlated with green biomass of tree components. The coefficient of determination, Ftest and standard error analysis indicated that the DBH was the best variable to use to estimate biomass of tree components.

Scatter plots of green biomass with DBH are shown in figure 4. Scatter plots showed positive linear relationships. The Pearson's correlation coefficient was calculated using SPSS computer software to analyse the strength of linear relationship between $\mathrm{DBH}$ and biomass.

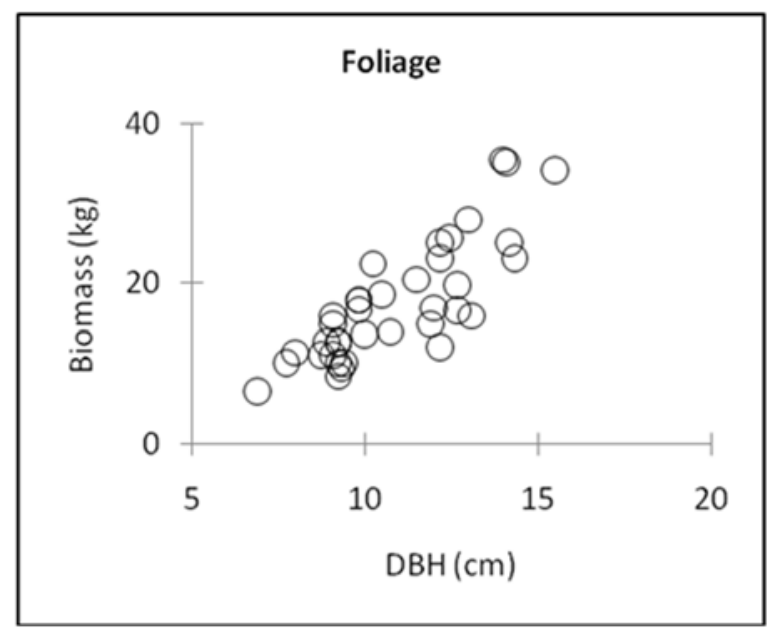



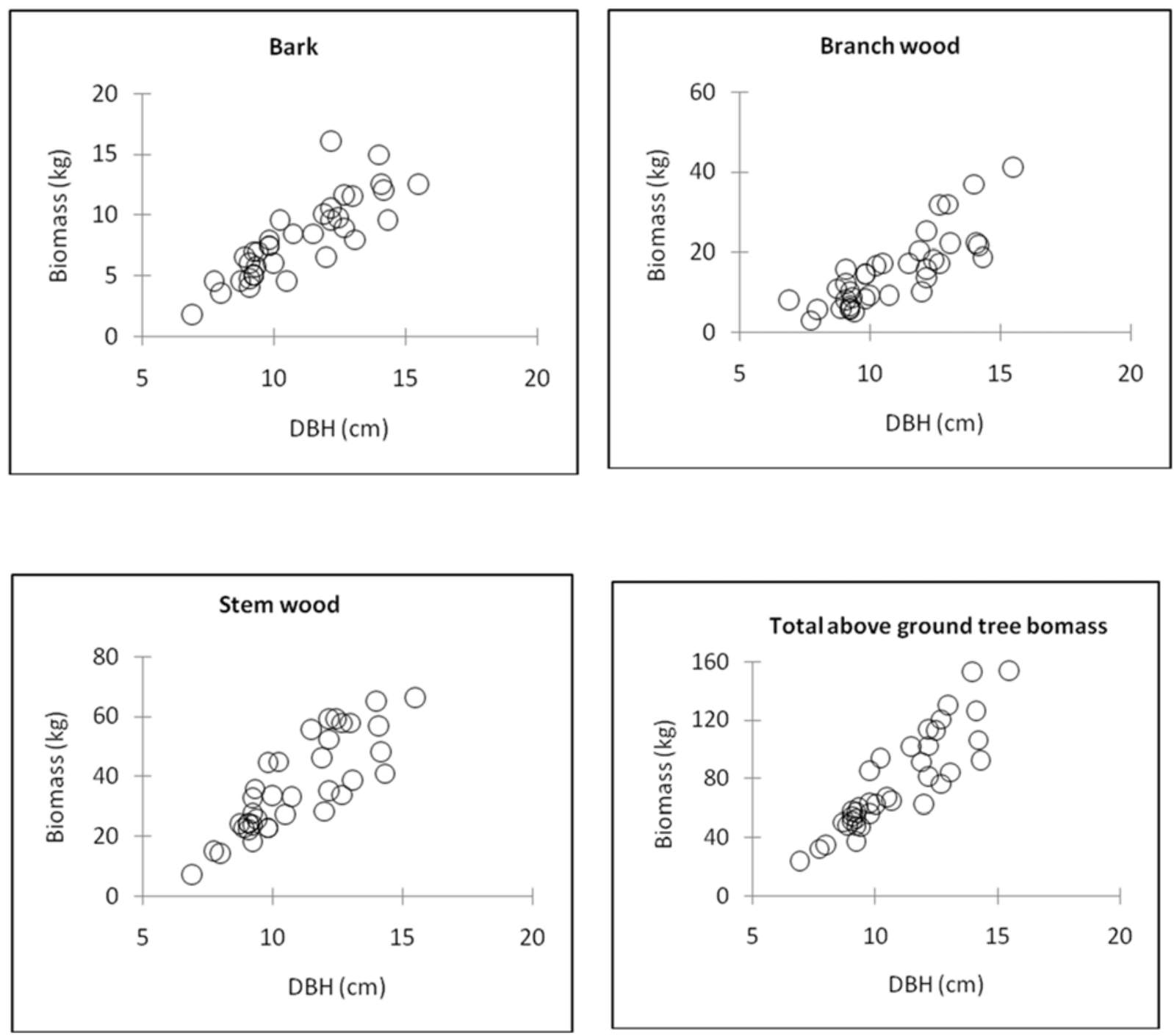

Fig 4: Relation between DBH and green weight of different tree components

The correlation coefficient of DBH with bark, foliage, branch wood, stem wood and total above ground tree biomass was $0.84,0.82,0.82,0.83$ and 0.89 , respectively. The relationship was found to be stronger for total above ground and bark biomass compared to other components. The correlation was highly significant $(p<0.001)$ for all cases. The correlation coefficient of more than 0.70 is usually considered strong relationship (Reimann et al., 2008). It shows that there is strong positive linear relationship between DBH and biomass of different tree components.

\section{Green biomass allometric models}

The green weight of tree components per tree was calculated from models describing the correlation between DBH $(\mathrm{cm})$ and green weight $\left(\mathrm{kg} \mathrm{tree}^{-1}\right)$, derived from data collected from field. Five

functions (linear, logarithmic, quadratic, power and exponential) were tested:

$$
\begin{array}{ll}
\mathrm{W}=\mathrm{b}_{0}+\mathrm{b}_{1} \mathrm{DBH} & \text { (Linear) } \\
\mathrm{W}=\mathrm{b}_{0}+\mathrm{b}_{1} \ln (\mathrm{DBH}) & \text { (Logarithmic) } \\
\mathrm{W}=\mathrm{b}_{0}+\mathrm{b}_{1}(\mathrm{DBH})+\mathrm{b}_{2}\left(\mathrm{DBH}^{2}\right) & \text { (Quadratic) } \\
\mathrm{W}=\mathrm{b}_{0} \mathrm{DBH} \mathrm{H}^{\mathrm{b} 1} & \text { (Power) } \\
\mathrm{W}=\mathrm{b}_{0} \mathrm{e}^{\mathrm{b} \text { bB }} & \text { (Exponential) }
\end{array}
$$

Where

$\mathrm{W}=$ Green biomass, $\mathrm{kg}$ tree $^{-1}$

$\mathrm{DBH}=$ Diameter at breast height measured at 1.3

$\mathrm{m}$ above the ground level, over bark, $\mathrm{cm}$ $\mathrm{b}_{0}, \mathrm{~b}_{1}$ and $\mathrm{b}_{2}$ are parameters.

These models were used to describe the relationship between DBH and green weight of tree components as such functions are often used when predicting 
biomass (Johansson and Karacic, 2011; Johansson, 1999; Satoo and Madgewick, 1982; Payandeh, 1981). Comparisons of the test statistics using different regression equations for different tree components in green condition are shown in table 2 .

All five models were found to be statistically significant $(p<0.01)$ based on F-test. Regression coefficients were tested for significance $(p<0.05)$ using t-test. Regression coefficients were significant $(p<0.05)$ in linear, logarithmic, power and exponential models for the prediction of foliage, bark and total above ground tree biomass. The regression coefficients of quadratic models were not significant. This is because of deliberate introduction of collineariity between $\mathrm{DBH}$ and $\mathrm{DBH}^{2}$. Similarly, coefficients of power model were not significant ( $>0.05)$ for branch and stem wood prediction.

Table 2: Regression models with model calibration and validation statistics relating tree DBH with green biomass of different tree components

\begin{tabular}{|c|c|c|c|c|c|c|c|c|c|}
\hline \multirow[t]{2}{*}{ Models } & \multicolumn{2}{|c|}{ Parameter estimates } & \multirow[b]{2}{*}{$\mathrm{b}_{2}$} & \multicolumn{4}{|c|}{ Model calibration $(\mathbf{N}=37)$} & \multicolumn{2}{|c|}{ Model validation $(\mathrm{N}=16)$} \\
\hline & $\mathrm{b}_{0}$ & $\mathrm{~b}_{1}$ & & $\mathrm{R}^{2}$ & SEE & $\mathrm{df}$ & F-value & RMSE (kg) & RMSE (\%) \\
\hline \multicolumn{10}{|l|}{ Foliage } \\
\hline Linear & $-13.671 * *$ & $2.8725^{* *}$ & \multirow{5}{*}{0.1804} & 0.677 & 4.294 & 35 & $73.35^{* *}$ & 4.07 & 25.11 \\
\hline Logarithmic & $-55.041 * *$ & $30.6655^{* *}$ & & 0.654 & 4.441 & 35 & $66.27 * *$ & 4.42 & 27.25 \\
\hline Quadratic & 8.1104 & -1.1653 & & 0.689 & 4.274 & 34 & $37.69 * *$ & 3.97 & 24.49 \\
\hline Power & $0.2569^{*}$ & $1.7493^{* *}$ & & 0.693 & 0.232 & 35 & $78.97 * *$ & 4.06 & 25.01 \\
\hline $\begin{array}{l}\text { Exponential } \\
\text { Bark }\end{array}$ & $2.8197 * *$ & $0.1606^{* *}$ & & 0.688 & 0.234 & 35 & $77.25^{* *}$ & 4.23 & 26.13 \\
\hline Linear & $-6.0773 * *$ & $1.2911^{* *}$ & \multirow{5}{*}{-0.0768} & 0.707 & 1.797 & 35 & $84.57 * *$ & 1.21 & 18.16 \\
\hline Logarithmic & $-25.459^{* *}$ & $14.1159^{* *}$ & & 0.717 & 1.767 & 35 & $88.71^{* *}$ & 1.27 & 19.03 \\
\hline Quadratic & -15.3480 & $3.0098^{*}$ & & 0.719 & 1.788 & 34 & $43.43^{* *}$ & 1.24 & 18.57 \\
\hline Power & $0.0643^{*}$ & $1.9971 * *$ & & 0.745 & 0.233 & 35 & $102.04 * *$ & 1.56 & 23.36 \\
\hline $\begin{array}{l}\text { Exponential } \\
\text { Branch }\end{array}$ & $1.0436^{* *}$ & $0.1785^{* *}$ & & 0.701 & 0.252 & 35 & $82.15^{* *}$ & 1.94 & 29.11 \\
\hline Linear & $-23.070 * *$ & $3.5204 * *$ & \multirow{5}{*}{0.2981} & 0.672 & 5.326 & 35 & $71.60 * *$ & 5.77 & 44.82 \\
\hline Logarithmic & $-73.183^{* *}$ & $37.3339 * *$ & & 0.641 & 5.572 & 35 & $62.41 * *$ & 5.89 & 45.70 \\
\hline Quadratic & 12.9325 & -3.1537 & & 0.694 & 5.220 & 34 & $38.49 * *$ & 6.31 & 48.98 \\
\hline Power & 0.0293 & $2.5667 * *$ & & 0.674 & 0.356 & 35 & $72.28^{* *}$ & 6.15 & 47.72 \\
\hline \multicolumn{9}{|l|}{ Stem wood } & \\
\hline Linear & $-30.602^{* *}$ & $6.1684^{* *}$ & \multirow{5}{*}{-0.4091} & 0.695 & 8.843 & 35 & $79.75^{* *}$ & 4.24 & 15.82 \\
\hline Logarithmic & $-123 . .56^{* *}$ & $67.5936^{* *}$ & & 0.708 & 8.655 & 35 & $84.79 * *$ & 4.61 & 17.18 \\
\hline Quadratic & $-80.004^{*}$ & $15.3266^{*}$ & & 0.709 & 8.764 & 34 & $41.40^{* *}$ & 4.72 & 17.60 \\
\hline Power & 0.2018 & $2.1507^{*}$ & & 0.732 & 0.259 & 35 & $95.61 * *$ & 5.59 & 20.83 \\
\hline Exponential & $4.1068^{* *}$ & $0.1912^{* *}$ & & 0.682 & 0.283 & 35 & $75.00^{* *}$ & 7.85 & 29.29 \\
\hline \multicolumn{10}{|c|}{ Total above ground tree biomass } \\
\hline Linear & $-73.421 * *$ & $13.8525^{* *}$ & \multirow{5}{*}{-0.0074} & 0.789 & 15.49 & 35 & $131.06^{* *}$ & 10.41 & 16.64 \\
\hline Logarithmic & $-277.25^{* *}$ & $149.709^{* *}$ & & 0.782 & 15.76 & 35 & $125.45^{* *}$ & 11.96 & 19.12 \\
\hline Quadratic & -74.309 & 14.0173 & & 0.789 & 15.72 & 34 & $63.66^{* *}$ & 10.41 & 16.64 \\
\hline Power & $0.5201^{* *}$ & $2.0726^{* *}$ & & 0.831 & 0.186 & 35 & $172.20 * *$ & 12.79 & 20.44 \\
\hline Exponential & $9.1694^{* *}$ & $0.1874 * *$ & & 0.801 & 0.202 & 35 & $140.79 * *$ & 17.37 & 27.76 \\
\hline
\end{tabular}

$\mathrm{R}^{2}$ - coefficient of determination, $\mathrm{df}=$ degree of freedom, SEE - standard error of estimates, $\mathrm{b}_{0}, \mathrm{~b}_{1}$ and $\mathrm{b}_{2}$ are parameter estimates, RMSE - root mean square error, ${ }^{* *}-p<0.01, *_{-} p<0.05$ 


\section{Model comparison}

The quadratic model was found to have the least error for the estimation of foliage biomass whereas linear model was to have the least error for the prediction of bark, branch, stem wood and total above ground biomass compared to other models. However, linear model was selected for the prediction of foliage biomass because of its simplicity in use and more importantly, the difference in RMSE for linear and quadratic was found minimal (25.11\% vs. $24.49 \%$ ). RMSE for the prediction of biomass ranged from $15.82 \%$ for stem wood biomass to $44.82 \%$ for branch wood biomass. Linear model was chosen for the prediction of total above ground biomass of Tejpat tree based on significant regression coefficients and also due to its simplicity where RMSE values for both models were equal. Hawkins (1987) has used logarithmic transformation of the power model to predict biomass for Eucalyptus camaldulensis, Dalbergia sissoo, Acacia auriculoformis and Casia siamea in the central Bhawar-Terai of Nepal. The same model was also used by Thapa (2000) to estimate biomass of Acacia auriculoformis, Acacia catechu, Dalbergia sissoo, Eucalyptus camaldulensis, Eucalyptus tereticornis and Leucaena leucocephala planted at Tarahara of Sunsari district.

Linear regression indicated a small RMSE of 1.21 $\mathrm{kg}$, which is approximately $18 \%$ of the average bark biomass of the validation trees. The linear regression model explained $70 \%$ of the variance associated with the field-measured bark biomass. Analyses showed that a high $\mathrm{R}^{2}$ and a low RMSE value for all tree components including total above ground biomass except branch wood indicates a good fit between the model developed and sample data. The lowest RMSE was found in the linear model, so it is not suitable to predict the branch wood biomass because of high RMSE value (44.82\%). Satoo and Madgwick (1982) found that the prediction of foliage biomass was less accurate than other components. But in our case, biomass prediction of branch (and foliage to some extent) was found less accurate. This may perhaps be due to site specific differences in quality and competition as explained by Hawkins (1987).

Thus, the best prediction of green weight (W) of different tree components of Tejpat tree are,

$\mathrm{W}($ Foliage $)=-13.671+2.8725 * \mathrm{DBH}$

$\mathrm{W}($ Bark $)=-5.8194+1.2700 * \mathrm{DBH}$

$\mathrm{W}($ Branch wood $)=-23.0700-3.5204 * \mathrm{DBH}$

$\mathrm{W}($ Stem wood $)=-30.6020+6.1684 * \mathrm{DBH}$

$\mathrm{W}$ (above ground tree $)=-73.4210+13.8525 * \mathrm{DBH}$

\section{Air-dry and oven-dry biomass of foliage and bark}

Based on laboratory analysis an air-dry weight to fresh weight ratio of foliage was 0.5543 and oven-dry weight to fresh weight ratio was 0.4309 . Similarly, air-dry weight to fresh weight ratio of bark was found to be 0.6369 and oven-dry to fresh weight ratio was 0.5429 .

Model calibration and validation for air-dry and oven-dry weight of bark and foliage through regression analyses showed the same statistics because these only differ from the green weight equations by a constant factor. However, the parameter estimates are, obviously, different and are given in appendix. Based on $\mathrm{R}^{2}$ value and $\mathrm{RMSE} \%$ obtained, the linear model was used to predict biomass of bark and foliage at air-dry and oven-dry conditions. The biomass table of bark and fresh foliage for fresh, air-dry and oven-dry conditions and branch wood, stem wood and total-above ground biomass at fresh condition is prepared by using above mentioned equations (Appendix 1).

\section{Application of the models}

Biomass equations are normally prepared on an oven-dry weight basis to facilitate comparison with other sites, species and seasons (Hawkins, 1987). Tejpat is of immense potential to earn income from bark and foliage in the study districts. Only the bark and foliage biomass at air-dry and oven-dry conditions is prepared. This will serve as a easyreference for the farmers to predict the fresh weight of their standing Tejpat trees as well as air-dry and oven-dry weight of bark and foliage. The statistically significant equations are validated using tree biomass data obtained from the same area. Models having the least RMSE are selected for prediction of tree component biomass. The model and biomass table, accrued thereof, for branch wood are not suitable to predict biomass because of high error. Biomass table in fresh weight are easy to validate. However, the best-fit equations can be further validated using tree biomass data obtained from other locations, as well as from coppice tree crops.

\section{Conclusion}

Tejpat stands have many values and uses and their management can provide several benefits at local, national and global level. Farmers in the study districts have prioritized Tejpat depending on their needs to 
generate income out of foliage and bark. Biomass equations are developed from pole-sized trees. The stem component was the largest part of the aboveground biomass. However, this species is largely traded for their bark and foliage. Tree DBH seemed to be the best predictor for above-ground biomass of Tejpat. Linear regression models could predict properly the biomass of tree components. Biomass table can be prepared for individual trees using allometric equations. The results of this study demonstrate the usefulness of allometric equations for above-ground biomass estimation of individual Tejpat tree and tree components with good accuracy except branch wood. Management and utilization of Tejpat stands is important as a major source of income for many rural farmers in the area and also as a potential source of carbon sink in the context of climate change. More investigation is needed to understand biomass production over time to determine the rotation age. Climatic and edaphic factors affecting biomass need to be considered in further study.

\section{Acknowledgements}

This study was supported by Western Region Office of Natural Resource Management Sector Assistance Programme (NARMSAP) through Silviculture Working Group (SWG). The authors would like to thank DFO Gulmi, Arghakhanchi and Plapa districts and their staff for assistance in field work. The authors are thankful to the Tejpat growers for their cooperation during the field study. We are thankful to Mr. Hem Aryal and Mr. Michael Ollgard for their extended help during this study.

\section{References}

Applegate, G.B., Gilmour, D.A. and Mohns, B. 1988. The use of biomass estimations in the management of forests for fuelwood and fodder production. Commonwealth Forestry Review 67 (2): 141-148.

Applegate, G.B, Hawkins, T. and Thompson, I. S. 1985. Preliminary Guidelines for Biomass Studies in Nepal. Technical Note 2/85. Nepal Australia Forestry Project, Kathmandu, Nepal.

Brown, S. 1997. Estimating biomass and biomass change of tropical forests: A primer. FAO Forestry Paper No 34. FAO, Rome, Italy.
DFO Arghakhanchi. 2001. Arghakhanchi Jillama Tejpat Sarvekshana (in Nepali). District Forest Office, Arghakhanchi, Nepal.

DFO Gulmi. 2001. Jadibuti Chinari Pustika (in Nepali). District Forest Office, Gulmi, Nepal.

DFO Palpa. 2001. Jadibuti Pahichan Tatha Namuna Sankalan Pustika (in Nepali). District Forest Office, Palpa, Nepal.

DPR. 2006. Plants of Nepal: Fact Sheet. Government of Nepal/Ministry of Forests and Soil Conservation, Department of Plant Resources, Kathmandu, Nepal.

Edwards D. M. 1996. Non-timber Timber Forest Products from Nepal: Aspects of the trade in Medicinal and aromatic plants. FORSEC Monograph 1/96. Forest Research and Survey Center. His Majesty's Government of Nepal, Kathmandu, Nepal.

Gill, S.J., Biging, G.S. and Murphy E.C. 2000. Modeling conifer tree crown radius and estimating canopy cover. Forest Ecology and Management 126 (3): 405-416.

Hawkins, T. 1987. Volume and weight tables for Eucalyptus camaldulensis, Dalbergia sissoo, Acacia auriculoformis and Casia simea. Banko Janakari 1 (2): 29-30.

Johansson, T. 1999. Biomass equations for determining fractions of European aspen (Populus tremula L.) growing on abandoned farmland and some practical implications. Biomass and Bioenergy 17: 471-480.

Johansson, T. and Karacic, A. 2011. Increment and biomass in hybrid poplar and some practical implications. Biomass and Bioenergy 35: 1925-1934.

Jackson, J. K. 1994. Manual of Afforestation in Nepal. $2^{\text {nd }}$ edition. Forest Research and Survey Center, Kathmandu, Nepal.

Joshi M.R. 1985. Prediction of biomass in a Plantation Stand of Chir pine (Pinus roxburghii) in Nepal. M. Sc. Thesis. University of Oxford, UK.

Kirtikar M.K. 1992 (ed). The Wealth of India. A Dictionary of Indian Raw Materials and Industrial Products. Vol-3. Council of Scientific and Industrial Research, New Delhi, India. 
Leboeuf, A., Beaudoin, A., Fournier, R. A., Guindon, L., Luther, J.E. and Lambert, M.C. 2007. A shadow fraction method for mapping biomass of northern boreal black Spruce forests using Quickbird imagery. Remote Sensing of Environment 110 (4): 488-500.

Nath, A.J., Das, G., Das, A.K. 2009. Above ground standing biomass and carbon storage in village bamboos in north east India. Biomass and Bioenergy 33: $1188-1196$

Payandeh, A. 1981. Choosing regression models for biomass prediction equations. Forest Chronology 57: 229-232

Popescu, S.C. 2007. Estimating biomass of individual pine trees using airborne lidar. Biomass and Bioenergy, 31: 646-655.

Poudel, B. S., Bhandari, D. N. and Gautam, S. K. 2003. Preparation of Biomass Tables for Tejpat (Cinnamomum tamala). A research report submitted to NARMSAP, Western Region Office, Pokhara, Nepal

Reimann, C., Filzmoser, P., Garett, R. and Dutter, R. 2008. Statistical Data Analysis Explained: Applied Environmental Statistics with R. Wiley and Sons. Chichester, UK.

Rendle, A. B., 1979. The Classification of Flowering Plants. Vikas Publishing House Pvt Ltd. Gajiyabad, India.

Satto, T. and Madgwick, H. 1982. Forest Biomass. Martinus Nijhoff/Dr. W. Junk. The Hague, Netherland.
Schroeder, P., Brown, S., Mo, J., Birdsey, R. and Cieszewski, C. 1997. Biomass estimation for temperate broad leaf forests of the United States using inventory data. Forest Science 43: 424-434.

Sharma, E.R. and Pukkala, T. 1990. Volume Equations and Biomass Prediction of Forest Trees of Nepal. Forest Survey and Statistics Division, Ministry of Forest and Soil Conservation, Kathmandu, Nepal.

St Clair, J.B. 1993. Family differences in equations for predicting biomass and leaf area in Douglas Fir (Pseudotsuga menziesii var. menziesii) Forest Science 39: 743-755.

Tamrakar, P.R. 1999. Biomass Tables for KatusChilaune Forest Type. Research Leaflet No. 8. Department of Forest Research and Survey, Kathmandu, Nepal.

Thapa, H. B. 2000. Biomass estimation of some fast growing trees in the eastern Terai, Nepal. Banko Janakari 10 (2): 15-20.

Vermijst, T. and Telenius, B. 1999. Biomass estimation procedures in short rotation forestry. Forest Ecology and Management 121: 137-146.

Wallace, D. and Goffinet, B. 1989. Mean squared error of prediction as a criterion for evaluating and comparing system models. Ecological Modeling 44 (3-4): 299-306.

Zianis, D. 2008. Predicting mean above-ground forest biomass and its associated variance. Forest Ecology and Management 256: 1400-1407. 
Appendix 1: Biomass Table of Tejpat (Cinnamomum tamala)

\begin{tabular}{|c|c|c|c|c|c|c|c|c|c|}
\hline \multirow{2}{*}{$\begin{array}{l}\mathrm{DBH} \\
(\mathrm{cm})\end{array}$} & \multicolumn{5}{|c|}{ Green weight (kg) } & \multicolumn{2}{|c|}{$\begin{array}{c}\text { Air-dry weight } \\
\text { (kg) }\end{array}$} & \multicolumn{2}{|c|}{$\begin{array}{c}\text { Oven-dry weight } \\
\text { (kg) }\end{array}$} \\
\hline & Foliage & Bark & Branch & Stem & Total & Foliage & Bark & Foliage & Bark \\
\hline 5.0 & 0.69 & 0.38 & -5.47 & 0.24 & -4.16 & 0.38 & 0.24 & 0.30 & 0.21 \\
\hline 5.5 & 2.13 & 1.02 & -3.71 & 3.32 & 2.77 & 1.18 & 0.65 & 0.92 & 0.56 \\
\hline 6.0 & 3.56 & 1.67 & -1.95 & 6.41 & 9.69 & 1.98 & 1.06 & 1.54 & 0.91 \\
\hline 6.5 & 5.00 & 2.31 & -0.19 & 9.49 & 16.62 & 2.77 & 1.47 & 2.15 & 1.26 \\
\hline 7.0 & 6.44 & 2.96 & 1.57 & 12.58 & 23.55 & 3.57 & 1.89 & 2.77 & 1.61 \\
\hline 7.5 & 7.87 & 3.61 & 3.33 & 15.66 & 30.47 & 4.36 & 2.30 & 3.39 & 1.96 \\
\hline 8.0 & 9.31 & 4.25 & 5.09 & 18.75 & 37.40 & 5.16 & 2.71 & 4.01 & 2.31 \\
\hline 8.5 & 10.75 & 4.90 & 6.85 & 21.83 & 44.33 & 5.96 & 3.12 & 4.63 & 2.66 \\
\hline 9.0 & 12.18 & 5.54 & 8.61 & 24.91 & 51.25 & 6.75 & 3.53 & 5.25 & 3.01 \\
\hline 9.5 & 13.62 & 6.19 & 10.37 & 28.00 & 58.18 & 7.55 & 3.94 & 5.87 & 3.36 \\
\hline 10.0 & 15.05 & 6.83 & 12.13 & 31.08 & 65.10 & 8.35 & 4.35 & 6.49 & 3.71 \\
\hline 10.5 & 16.49 & 7.48 & 13.89 & 34.17 & 72.03 & 9.14 & 4.76 & 7.11 & 4.06 \\
\hline 11.0 & 17.93 & 8.12 & 15.65 & 37.25 & 78.96 & 9.94 & 5.17 & 7.72 & 4.41 \\
\hline 11.5 & 19.36 & 8.77 & 17.41 & 40.33 & 85.88 & 10.73 & 5.59 & 8.34 & 4.76 \\
\hline 12.0 & 20.80 & 9.42 & 19.17 & 43.42 & 92.81 & 11.53 & 6.00 & 8.96 & 5.11 \\
\hline 12.5 & 22.24 & 10.06 & 20.94 & 46.50 & 99.74 & 12.33 & 6.41 & 9.58 & 5.46 \\
\hline 13.0 & 23.67 & 10.71 & 22.70 & 49.59 & 106.66 & 13.12 & 6.82 & 10.20 & 5.81 \\
\hline 13.5 & 25.11 & 11.35 & 24.46 & 52.67 & 113.59 & 13.92 & 7.23 & 10.82 & 6.16 \\
\hline 14.0 & 26.54 & 12.00 & 26.22 & 55.76 & 120.51 & 14.71 & 7.64 & 11.44 & 6.51 \\
\hline 14.5 & 27.98 & 12.64 & 27.98 & 58.84 & 127.44 & 15.51 & 8.05 & 12.06 & 6.87 \\
\hline 15.0 & 29.42 & 13.29 & 29.74 & 61.92 & 134.37 & 16.31 & 8.46 & 12.68 & 7.22 \\
\hline 15.5 & 30.85 & 13.93 & 31.50 & 65.01 & 141.29 & 17.10 & 8.88 & 13.30 & 7.57 \\
\hline 16.0 & 32.29 & 14.58 & 33.26 & 68.09 & 148.22 & 17.90 & 9.29 & 13.91 & 7.92 \\
\hline 16.5 & 33.73 & 15.23 & 35.02 & 71.18 & 155.15 & 18.70 & 9.70 & 14.53 & 8.27 \\
\hline 17.0 & 35.16 & 15.87 & 36.78 & 74.26 & 162.07 & 19.49 & 10.11 & 15.15 & 8.62 \\
\hline 17.5 & 36.60 & 16.52 & 38.54 & 77.35 & 169.00 & 20.29 & 10.52 & 15.77 & 8.97 \\
\hline 18.0 & 38.03 & 17.16 & 40.30 & 80.43 & 175.92 & 21.08 & 10.93 & 16.39 & 9.32 \\
\hline 18.5 & -- & -- & -- & -- & -- & -- & -- & -- & -- \\
\hline
\end{tabular}

Numbers in italics are outside the sample DBH size.

Sample location: Arghakhanchi, Gulmi and Palpa districts

Green weight (Foliage): $b_{0}+b_{1}$ DBH

Green weight (Bark): $b_{0}+b_{1} \mathrm{DBH}$

Green weight (Branch): $b_{0}+b_{1} \mathrm{DBH}$

Green weight (Stem): $b_{0}+b_{1}$ DBH

Green weight (Total tree): $b_{0}+b_{1} \mathrm{DBH}$

Air-dry weight (Foliage): $b_{0}+b_{1} \mathrm{DBH}$

Air-dry weight (Bark): $b_{0}+b_{1} \mathrm{DBH}$

Oven-dry weight (Foliage): $\mathrm{b}_{0}+\mathrm{b}_{1} \mathrm{BH}$

Oven-dry weight (Bark): $b_{0}+b_{1} \mathrm{DBH}$
Diameter range $(\mathbf{c m}): 6.9$ to $15.5 \quad$ Number of trees: 53 trees Height range (m): 6.80 to 18.15 Diameter at DBH: $1.3 \mathrm{~m}$ $\left(b_{0}=-13.6710, b_{1}=2.8725, R^{2}=0.677\right.$, F-value $\left.=73.35, M S E \%=25.11\right)$ $\left(b_{0}=-6.0773, b_{1}=1.2911, R^{2}=0.707\right.$, F-value $\left.=84.57, \mathrm{RMSE} \%=18.16\right)$ $\left(b_{0}=-23.0700, b_{1}=3.5204, R^{2}=0.672\right.$, F-value $=71.60$, RMSE $\left.\%=44.82\right)$ $\left(b_{0}=-30.6020, b_{1}=6.1684, R^{2}=0.695\right.$, F-value $=79.75$, MSE $\left.\%=15.82\right)$ $\left(b_{0}=-73.421, b_{1}=13.8525, R^{2}=0.789 \mathrm{~F}-\right.$ value $\left.=131.06, \mathrm{SE} \%=16.64\right)$ $\left(b_{0}=-7.5779, b_{1}=1.5923, R^{2}=0.677, F-v a l u e=73.35, R M S E \%=25.11\right)$ $\left(b_{0}=-3.8706, b_{1}=0.8223, R^{2}=0.707\right.$, F-value $=84.57$, RMSE $\left.\%=18.16\right)$ $\left(b_{0}=-5.8909, b_{1}=1.2378, R^{2}=0.677\right.$, F-value $\left.=73.35, R M S E \%=25.11\right)$ $\left(b_{0}=-3.2994, b_{1}=0.7010, R^{2}=0.707\right.$, F-value $\left.=84.57, R M S E \%=18.16\right)$ 